\title{
ČíST AKČNÍ UMĚNí. TEXTY VÁZAJÍCÍ SE K UMĚLECKÝM AKCÍM 60.-80. LET 20. STOLETÍ V ČESKOSLOVENSKU1
}

\author{
ZDISLAVA MELICHAROVÁ RYANTOVÁ \\ Ústav pro dějiny umění, Filozofická fakulta Univerzity Karlovy \\ E-mail:zryantova@seznam.cz
}

\begin{abstract}
Reading Action Art. Texts relating to art events in Czechoslovakia from the 1960s to 1980s

As a documentation material, the text is often overshadowed by photography - but unlike photography, it can mediate the processual character of performance art. In terms of form, it is possible to discern a typology of texts and assign each type to a particular literary genre. This paper is concerned with the description of an art event, which can be defined as the literary genre of "ekphrasis" (the discipline of art pieces description). Depending on the nature of the artwork, both ekphrasis and descriptions of art events are produced in between narration and description, as well as oscillate between interpretation and pure description. To illustrate this, several examples from the Czech scene of the 1960s to 1980s will be presented. Not only the content of the text but also its form determines our "reading" of the described artwork - in this case, the reception of art events of the last decades.
\end{abstract}

Keywords: Czech action art of the 1960s-1980s; documentation of art; description; ekphrasis

$\mathrm{V}$ př́padě akčního umění uplynulých dekád je recipient (pokud u akce nebyl př́itomen) odkázán především na dokumentaci těchto akcí. Z tohoto období existuje jen malé množství časových záznamů (videozáznamů), proto lze vycházet především z fotografií. Procesuálnost událostí pak zprostředkovává text, kterým jsou většinou fotografie nebo samotné akce popisovány, dovysvětlovány či interpretovány. Přestože právě texty podávají o akcích většinu informací, je jim v kontextu dokumentace akčního umění věnováno méně pozornosti než např. fotografii.

\section{Vztah fotografie a textu}

Jako forma dokumentace zastávají texty vedle fotografí́ spornou pozici, nebở fotografie na rozdíl od textu musela vzniknout ve stejnou chvíli jako akce. Proto vedle ní může text jen stěží obstát jako důkaz (o uskutečnění akce) či artefakt, za které je fotografie tradičně považována. Fotografii přidává na věrohodnosti také její indexikální

1 Text př́mo vychází $\mathrm{z}$ mé diplomové práce s názvem Role textu ve vnímání umění akce 60. a 70. let $v$ ČSSR obhájené v roce 2015 na Fakultě umění a designu Univerzity Jana Evangelisty Purkyně v Ústí nad Labem. 
charakter - je tvořena na základě kauzálního vztahu k tomu, co zobrazuje. Není pouze analogickým zobrazením fotografované skutečnosti na základě podobnosti, jako by tomu bylo např. u kresby. „[Fotografický obraz] je zároveň i otiskem reality, znakem, který byl skutečně, zasažen'zobrazeným objektem - referentem. V Peirceově terminologii je nazýván indexem - tzn. př́znakem, diokazem. “2 Fotografie je „důsledkem“ objektu, objekt se před fotoaparátem musel skutečně vyskytovat.

Fotografie je mnohdy mylně automaticky považována nejen za důkaz, že se akce udála, ale že se také udála přesně tak, jak je na ní zobrazeno. Ale i takový obraz je pouze interpretací, a nikoliv důkazem, nebot je výřezem obrazu, před kterým fotograf stojí. Závisí především na fotografově výběru a postprodukci, která fotografii upravuje - je tedy konečně podobně jako text přístupná široké manipulaci. ${ }^{3}$ Výřez, který lze spatřit na fotografii, není ale výřezem situace. Může jít o manipulovanou kompozici, která je uspořádána přímo pro fotografický obraz. Přestože je ale iluzivní objektivita fotografického záznamu „odhalena“, je fotografie ve společenském povědomí stále ukotvena jako věrohodné médium.

Vyvstává zde ale otázka, zda fotografie nepotřebuje pro svou legitimitu text, stejně jako text v kontextu dokumentace umění potřebuje ke své verifikaci fotografii. Beaumont Newhall naopak tvrdí, že nelze fotografii považovat za dokument, pokud není nejprve sama zdokumentována - umístěna v čase a prostoru. ${ }^{4}$

\section{Text ve vztahu k akčnímu umění}

Všechny shromážděné (přečtené) texty k jednotlivým uměleckým akcím, at’ už se jedná o texty primární, doplňující fotografickou dokumentaci či o sekundární texty v odborných publikacích, utvářejí recipientovo povědomí o těchto akcích a také ovlivňují texty, které o akcích teprve vzniknou. Texty lze doplňovat a vrstvit v nekonečné textové kompiláty plné interpretací, ve většině případů ale existuje určitý primární text, který byl autorem archivován spolu s fotografiemi a s trochou nadsázky ho lze považovat za základní kámen pro další interpretace. Zvláště tyto texty jsou zdrojem pro zkoumání autorovy intence a pro komparaci se sekundárními texty nezúčastněných osob. Texty lze dle jejich literárních forem a společných znaků dělit do určitých kategorií. Každý typ textu (literární forma) předpokládá specifický styl čtení; přeneseně mohou tedy texty ovlivnit také „čteni'“ - vnímání určité umělecké akce. Nejčetnějším literárním žánrem (ale zdaleka ne jediným) vyskytujícím se v kontextu akčního umění jsou různé formy popisu a právě těmi se bude př́spěvek níže zabývat.

2 Petra Trnková, Fotografie po dějinách umělecké fotografie, in: Marta Filipová - Matthew Rampley (edd.), Možnosti vizuálních studií. Obrazy - texty - interpretace, Brno 2007, s. 104.

3 Jan Krtička, Dokumentace akčního umění (disertační práce), FUD UJEP, Ústí nad Labem 2014, s. 57.

4 Beaumont Newhall, The History of Photography from 1839 to the prezent, London 1983, s. 246. 


\section{Popis: Ekfráze}

Popis stále není jasně vymezeným žánrem a názory na jeho definice se velmi liší. Stanislava Fedrová a Alice Jedličková, které se popisem v literatuře zabývají dlouhodobě, charakterizují současné uvažování o popisu na základě studie Wernera Wolfa mimo jiné takto: „Popis sděluje převážně smyslová data získaná pozorováním dané skutečnosti; popis zajištuje spiše objektivní informaci než vysvětlení či evaluaci (to platí zvláště pro př́rodní vědy; ve vědách humanitních je popis stavěn spiše do opozice $k$ interpretaci). “5 Právě otázka interpretačního potenciálu popisu je ale v kontextu uměleckých akcí podstatná. V hojné míre se vyskytují autorské popisy, které jsou psány v první osobě a mají velmi strohou formu. I v těchto krátkých sděleních lze hledat intenci autora, která navíc může čtenáŕi implikovat určitou interpretaci.

Pro užší charakteristiku popisů vázajících se k uměleckým akcím lze využít definic pojmu ekfráze jakožto specifické kategorie popisu. Ekfráze je termín pocházející z antiky, je spojován s popisem uměleckého díla a tradičně používán $\mathrm{v}$ uměleckohistorickém diskurzu. Nejšíře by se dal definovat jako „verbální reprezentace vizuální reprezentace“ ${ }^{6}$ Její funkcí je tedy převedení jednoho média do druhého, konkrétně vizuálního do textového. Nejznámějšími antickými ekfrázemi jsou mimo jiné Filostratovy popisy obrazů z předměstské vily u Neapole, v níž pobýval. Tyto nedochované ${ }^{\circ}$ obrazy jsou známy jen z Filostratových popisů či skrze reinterpretace jiných malíruu, kteří je ale nikdy neviděli. Umělecké akce jsou ze své podstaty pomíjivé a nelze je stejně jako obrazy popsané Filostratem znovu spatřit a zhodnotit na základě vlastní zkušenosti. Podobně jako „Filostratovy obrazy“ si lze proběhlé akce představovat, hodnotit a interpretovat zejména na základě jejich popisů. Popis pak naplňuje svou reprezentační a prezentační funkci: zprostředkovává nepř́tomné a vzdálené. ${ }^{8}$

V diskusích kolem ekfráze, at už na uměleckohistorickém nebo na literárněvědném poli, se objevuje zvláštní snaha definovat tento pojem na základě vztahu mezi narativitou a deskripcí a vztahu mezi interpretací a deskripcí. Podobné rozpětí ekfrastických textů lze najít i v kontextu akčního umění.

\section{Mezi narativitou a deskripcí}

Ekfráze se většinou realizuje v různé míře oběma směry, jak popisem, tak vyprávěním. Tradiční pojetí tohoto žánru definuje ekfrázi jako popis statických obrazů, které jsou jím uváděny do pohybu a odkrývají děj. Nemusí se jednat př́mo o vyprávění, ale o jistou „dějovost", která je důsledkem narativního impulzu, jenž je v žánru ekfráze implicitně př́to-

Stanislava Fedrová - Alice Jedličková, Konec literárního špenátu aneb Popis v intermediální perspektivě, Česká literatura LIX, 2011, č. 1, s. 34.

6 "[E]kphrasis is the verbal representation of visual representation. "James Heffernan, Museum of Words. The poetics of Ekphrasis from Homer to Ashbery, Chicago 2004, s. 3.

7 Nelze s jistotou určit, zda Filostratos popisoval skutečné obrazy či se jednalo o pouhé rétorické cvičení. V druhém př́padě by se jednalo o tzv. fiktivní ekfrázi, která se váže k neexistujícím uměleckým dílům. Analogicky lze nalézt popisy uměleckých akcí, které se neuskutečnily. Lubomír Konečný, Hra o jablko. Karel Škréta a Filostratos, Opuscula historiae artium LI, 2002, č. 46, s. 13.

Viz Fedrová - Jedličková (pozn. 5), s. 34. 
men. ${ }^{9}$ Ekfráze pak rozvíjí okamžik zastavený v obraze, který je „těhotný dějem“. ${ }^{10}$ Akční umění má v sobě časovost již obsaženou a popisy těchto akcí budou vždy obsahovat jistý prvek narativity, nebot sledují děj v čase. Nedochází zde tedy k převodu statického díla na časové, ale pouze $\mathrm{k}$ převodu vizuálního díla na textové.

Ekfráze rozvíjí v obraze časovost a pohyb. Stále je ale předmětem diskusí otázka, zda je ekfrastický popis statické, nebo spíše dynamické povahy. Statická ekfráze se zaměřuje na přesné vyjádření prostoru, zmiňuje detaily, využívá četně výrazů, které označují výskyt či přítomnost, a naopak časové výrazy zde chybí. Dynamická povaha se vyznačuje časovým vnímáním, četností časových výrazů a v neposlední řadě popisem událostí v určitém pořadí; popisuje „příběh“. ${ }^{11}$ Povaha popisu se rozvíjí zejména v závislosti na znalosti viděného obrazu. Pokud ti, kteří obraz popisují, znali jeho námět nebo osoby na něm zobrazené již dříve, bude jejich popis dynamičtější. Pokud výjev vidí poprvé, budou se soustředit spíše na statický popis materiální stránky obrazu. ${ }^{12} \mathrm{~V}$ př́padě akčního umění bude jinak popisovat událost pozorovatel, který účastníky zná, a jinak náhodný kolemjdoucí. Př́ikladem dynamického popisu, který se nezaměřuje tolik na samotnou scénu jako spíše na symbolickou rovinu akce a prožitek osob, může být popis momentu na konci Druhé manifestace aktuálního umění (1965) Jindřicha Chalupeckého. Jako zasvěcený divák znalý kontextu rozeznává v aktu pálení šatů Soni Švecové symbolický podtext. Kromě jisté interpretace vyniká Chalupeckého popis sugestivitou, které by těžko mohl v popisu dosáhnout náhodný kolemjdoucí. „To zůstali tam ještě pár dlouhých chvil mlčky stát; okouzleně se dívali do plápolajícího ohně, poslouchali jeho praskot a nejasnè si uvědomovali, že v tom nudném a kalném poledni sychravé městské neděle, pár kroků od široké třídy, odkud k nim chvílemi zazníval hluk projiždějících tramvají a aut, se před nimi odehrál v symbolické podobě archaický ritus upálení panny. "13

Antické ekfráze se většinou vztahovaly k obrazům, které měly literární předlohu. Většina $\mathrm{z}$ šedesáti pěti obrazů, které Filostratos popisuje, se zakládala na všeobecně známých mytologických příbězích. Také některé umělecké akce následovaly určitou literární předlohu. Dle Emmy Tornborg bude popis obrazu (akce, příp. fotografie $\mathrm{z}$ akce) narativnější a dynamičtější povahy v př́ípadě, že divák zná zápletku obrazu (např. postavy nebo námět, který obraz zpodobňuje). ${ }^{14}$ Zorka Ságlová uskutečnila několik akcí v prŕírodě, které založila na určité legendě. Ve dvou případech byla legenda spojena s místem, na kterém akce probíhala. Kladení plen u Sudoměre (1970) je doprovázeno tímto autorčiným popisem: „Na místě bitvy jsme rozložili na trávu asi 700 čtverců bílé tkaniny do tvaru velkého trojúhelníku a nechali je tam. "15 Tento text nepodává více informací, než je nezbytné, s čímž se u autorských textů setkáváme často. Naopak text Lenky Bučilové se soustředuje především na děj legendy: „Několik měsíců nato, v květnu 1970, uspořádala Zorka Ságlová [...] akci Kladení plín u Sudoměře na louce, která byla kdysi místem slavné bitvy. Legenda praví, že historickou bitvu, která se na tomto místě odehrála, rozhodly husitské ženy, které

\footnotetext{
Viz Konečný (pozn. 7), s. 17.

10 Viz Heffernan (pozn. 6), s. 3.

11 Emma Tornborg, To podstatné je čas. Temporální transformace v ekfrázi, in: Alice Jedličková (ed.), O popisu, Praha 2014, s. 78.

2 Ibidem, s. 80-81.

13 Jindřich Chalupecký, Na hranicích umění. Několik př́iběhư, München 1987, s. 94.

14 Viz Tornborg (pozn. 11), s. 80-81.

15 Lenka Bučilová, Zorka Ságlová. Úplný prehled díla, Praha 2009, s. 21.
} 
nakladly své šátky na mokřiny podél hráze, takže když jezdci s těžkou výzbrojí vjeli na tato místa, začali se propadat do bahna, což jim znemožnilo pohyb, a husité je tak snadno pobili. Tyto šátky vystřídaly dětské pleny, jejichž ručním praním se autorka zabývala vlastně denně od chvíle, kdy se jí v roce 1968 narodila dcera. Když pak z metráže nastříhala 700 takových bílých plen a rozložila je $v$ souladu s tvarem krajiny do trojúhelníku, uskutečnila nejen vysoce estetickou promènu této krajiny, ale nevyhnula se ani vyvolání otázek po historických souvislostech svého počinání na takovém místěe "16 Jiř́ Valoch v monografii o Zorce Ságlové také neopomine zmínit legendu, která stojí v pozadí akce: „[Zorka Ságlová] vytvořila u Sudoměře, kde svedla husitská vojska legendární bitvu, kterou údajně rozhodly rozložené látkové pleny, na několika polích z asi sedmi set čtverců bílé tkaniny veliký trojúhelník." 17 Pozorovatel, který by legendu neznal, se bude soustřed’ovat spíše na detaily rozložení plen, počet účastníků akce atd. a jeho popis bude spíše statický. Naopak popisy vycházející z legendické předlohy nabývají narativní povahy. Pokud legenda o ženách, které během husitských válek kladly pleny u Sudoměře, není divákovi neznámá, poskytuje mu její narativní struktura pro tuto uměleckou akci interpretační matrici. ${ }^{18}$

V těchto případech dochází ke zdvojenému intermediálnímu aktu. Původní literární (nebo verbální) legenda je převedena do média happeningu, který je následně popsán. Čtenář poznává happening skrze popis, který mu zprostředkovává také původní literární předobraz. Na druhou stranu se ale může čtenáři pomocí znalosti literární legendy dostat interpretační matrice, která mu pomáhá „př̌číst“ konkrétní happening.

\section{Mezi interpretací a deskripcí}

Druhým bodem diskusí na poli ekfráze je spor o její interpretační či deskriptivní charakter. Idea, že ekfráze je „čistý“, tedy neinterpretační popis, je dnes již překonaná, přesto někteří badatelé stále odkazují na jistou „objektivitu deskripce“. ${ }^{19}$ Druhým extrémem je tvrzení, že ekfráze je přímo diktováním interpretace. ${ }^{20}$ Pozorovatel uměleckého díla se může snažit skrze popis o objektivní zprostředkování viděné skutečnosti, stěží v něm ale nebude obsažena určitá pozorovatelská intence. Dokumentaci uměleckých akcí v hojném počtu doprovázejí autorské texty psané v ich-formě, které jsou př́íznačné svou strohou krátkou formou. Důvodem může být snaha podat o akci exaktní informace, které se přibližují svou formou vědecké dokumentaci, čímž mají navodit pocit věrohodnosti, či snaha popis oprostit od jakékoliv interpretace. (Např. Marian Palla: „Dne 21. 1. 1981 $v 18$ hod. jsem vstoupil na obraz o rozmèrech $120 \times 180 \mathrm{~cm}$ umístèný na zemi a strávil na něm bez přerušení dva dny. Po tuto dobu jsem jedl pouze přepočítanou rýži a pil čaj. Dne 23. 1. 1981 jsem z obrazu vystoupil. “21) Přestože autorské texty nejsou přímo interpretační, může autorská intence k určité interpretaci nabádat. Důvodem k použití strohého

\footnotetext{
Ibidem, s. 21.

7 Jiří Valoch, Cesta tvorby Zorky Ságlové, in: Milan Knízák (ed.), Zorka Ságlová, Praha 2006, s. 20.

8 Viz Fedrová - Jedličková (pozn. 5), s. 34.

19 Např. David Carrier, Werner Wolf.

20 Stanislava Fedrová, Popis a jeho subjekt. Očima pozorovatele, in: Alice Jedličková (ed.), O popisu, Praha 2014, s. 103-104.

21 Pavlína Morganová, Akční umění, Olomouc 2009, s. 179.
} 
textu může být např. zdůraznění podstaty akce, zdůraznění symboliky a vážnosti nebo evokování pocitu absurdity.

Petr Rezek na základě strohých autorských textů charakterizuje umění performance ze 70. let. Uvádí, že od vyprávění typu „mazal jsem chleba máslem“ očekáváme uvedení něčeho, co přijde potom, nebo že znamená „zatímco jsem si mazal chleba máslem, něco se stalo“. Stejně tak se ptá, zda by vůbec někdo někomu vyprávěl pouze to, „že jsem vystoupil na horu za špatného počasí" (zde odkazuje na akci Jana Mlčocha, kterou doprovází autorský komentář: „Za špatného počasí, prudkého větru, sněžení a mlhy jsem vystoupil na horu Kotel. Šel jsem sám a cestou jsem fotografoval“). ${ }^{22}$ Běžně je takový typ vyprávění druhotným textem - doplňuje nějakou situaci, pointu. Ve chvíli, kdy ale stojí sám o sobě a neuvozuje nic než jen sám sebe, stává se důležitým jen toto sdělené. Tím, že je tento text vytržen z jakéhokoliv kontextu, je mu odebrána jeho druhotná pozice a dostává se na místo první. Skutečně jde tedy o to, že „jsem si namazal chleba máslem“. Jeví se potom jinak než v kontextu jiného dění. ${ }^{23}$

Strohé konstatování činnosti, kterou autor prováděl, může navádět čtenáře $\mathrm{k}$ jejímu určitému čtení - např. může svou formou evokovat vážnost rituálu. V rituálu přikládáme každému popsanému detailu důležité místo, protože očekáváme jistou symboliku. Také tyto strohé texty vedou čtenáře k symbolické interpretaci holého sdělení. Příkladem může být akce Mariana Pally Nevím (nedat.): „Uvařil jsem hrnec čaje a položil do něho na chvíli kámen. "24 Některé delší texty pak směrují čtenáře k interpretaci každého detailu; např̀. text k akci Petra Štembery Lukostřelec (1977): „V místnosti plné lidí jsem oblečen do nacistické košile vystřelil šíp, opatřený kovovou špicí, na terč na zdi, demonstrujíc (sic) sílu dětského luku. Pak jsem namočil druhý šip (který měl také kovovou špičku) v lahvičce označené JED, namíril na cíl, ale vystřelil do diváků na druhé straně zdi. “25

Jiné strohé popisy akcí svou jednoduchostí a vytržeností z kontextu mohou vzbuzovat pocit absurdity nebo vtipu. Př́́kladem je akce Mariana Pally Hledání: „8. 8. 1984 jsem zanesl kámen do zahrady a potom jsem ho šel hledat na pole. " 26 Marian Palla s absurdním vyzněním svých akcí pracuje systematicky, další ukázkou může být název výše popsané akce Na tomto obraze jsem existoval dva dny a snédl 7999 zrnek rýže (1981).

$\mathrm{V}$ některých případech nazírání na akce změní až dodatek jiného pozorovatele, který nemusí podle performera být podstatný, protože ho neuvedl ve své dokumentaci, ale čtenář po přijetí dodatečné informace mnohdy už nedokáže akci vnímat bez ní. Takový dodatečný popis se mnohdy nedá považovat př́mo za interpretační, čtenářovu vlastní interpretaci dané akce však ovlivňuje. Recipient proběhlých akcí je odkázán nejen na dokumentaci, ale na všechny texty, které k daným akcím vznikly. Forma jednotlivých textů ovlivňuje recipientovo vnímání a interpretaci těchto akcí, nebot’ se nemůže vrátit k samotné události. Texty, stejně jako např. fotografie, se pak stávají integrální součástí těchto uměleckých děl a je třeba zohlednit jejich vliv, např. na základě jejich literární formy, prri analýze jednotlivých akcí.

\footnotetext{
Karel Srp, Karel Miler, Petr Štembera, Jan Mlčoch. 1970-1980, Praha 1997, s. 11.

Petr Rezek, Tělo, věc a skutečnost v umění šedesátých a sedmdesátých let, Praha 2010, s. 117.

Viz Morganová (pozn. 20), s. 175.

Ibidem, s. 178.

Ibidem, s. 175.
} 


\section{LITERATURA}

Lenka Bučilová, Zorka Ságlová. Úplný prèehled díla, Praha 2009.

Stanislava Fedrová, Popis a jeho subjekt. Očima pozorovatele, in: Alice Jedličková (ed.), O popisu, Praha 2014, s. 94-109.

Stanislava Fedrová - Alice Jedličková, Konec literárního špenátu aneb Popis v intermediální perspektivě, Česká literatura LIX, 2011, č. 1, s. 26-58.

James Heffernan, Museum of Words. The poetics of Ekphrasis from Homer to Ashbery, Chicago 2004.

Jindřich Chalupecký, Na hranicích umění. Několik př́iběhů, München 1987.

Lubomír Konečný, Hra o jablko. Karel Škréta a Filostratos, Opuscula historiae artium LI, 2002, č. 46, s. 7-23.

Jan Krtička, Dokumentace akčního umění (disertační práce), FUD UJEP, Ústí nad Labem 2014.

Pavlína Morganová, Akční umění, Olomouc 2009.

Beaumont Newhall, The History of Photography from 1839 to the prezent, London 1983.

Petr Rezek, Tělo, věc a skutečnost v umění šedesátých a sedmdesátých let, Praha 2010.

Zdislava Ryantová, Role textu ve vnimání umèní akce 60. a 70. let v ČSSR (diplomová práce), FUD UJEP, Ústí nad Labem 2015.

Karel Srp, Karel Miler, Petr Štembera, Jan Mlčoch. 1970-1980, Praha 1997.

Emma Tornborg, To podstatné je čas. Temporální transformace v ekfrázi, in: Alice Jedličková (ed.), O popisu, Praha 2014, s. 73-93.

Petra Trnková, Fotografie po dějinách umělecké fotografie, in: Marta Filipová - Matthew Rampley (edd.), Možnosti vizuálních studií. Obrazy - texty - interpretace, Brno 2007, s. 93-110.

Jiří Valoch, Cesta tvorby Zorky Ságlové, in: Milan Knížák (ed.), Zorka Ságlová, Praha 2006, s. 15-28. 